UDC 339.9

DOI 10.33111/iep.2020.32_33.04_eng

\title{
Socially Responsible Activities of Construction Companies in International Supply Chains
}

\author{
DENISS DJAKONS ${ }^{1}$ \\ RUSTAM ASLANZADE ${ }^{2}$
}

\begin{abstract}
The article reveals the need and main directions for the formation of a socially responsible business in such an area of entrepreneurial activity as supply chain management. It is shown that this is a complex and integrated activity to generate all information about the in- and out-supply of a company within the general value chain, and it has been proven that an important aspect of modern civilized business is to ensure supply management based on the concept of corporate social responsibility (CSR), implementation of which in the field of supply management is an extremely important area of not only for the creation of a positive image of the company, but also for the increase of its competitiveness in global and regional markets for goods and services. The article summarizes the experience of global construction companies in implementation of the principles and tools of social responsibility in their supply chains. It has been proven that modern companies build the entire supply chain on the principles of social responsibility, among them, the key principles have been identified as compliance with standards of human and environmental safety, ethics, business conduct and protection of human rights. Mechanisms and criteria for selection of suppliers and subcontractors have been revealed. The key aspects of building relationships with stakeholders - own staff, suppliers and subcontractors, industry associations have been systematized. Construction companies - leaders and construction companies - followers in terms of the formation of trends in the development of corporate social responsibility policies for supply chains have been identified. The forms of indicators of socially responsible activity of international construction companies in supply chains have been revealed and characterized. The stages of building a supply chain on the basis of social responsibility for construction companies have been identified and characterized. It has been shown that: in modern conditions, a higher level of social responsibility is a situation where a company thinks not only about its internal activities, but also builds the entire supply chain on the principles of social responsibility by bringing forward requirements for all its potential counterparties, a company can expand its socially responsible influence on the business environment on a global scale.
\end{abstract}

KEYWORDS: corporate social responsibility (CSR), supply management, supply chains, logistics, supply chain management, principles of social responsibility, indicators of social responsibility.

* This article was translated from its original in Ukrainian

${ }^{1}$ Djakons Deniss - Dr.oec, Professor, Rector of ISMA University of Applied Sciences (ISMA) (Riga, Latvia). Sphere of scientific interest: higher education management, formation of competitiveness of higher education institutions in the context of globalization, innovation management. E-mail: deniss.djakons@isma.lv

${ }^{2}$ Aslanzade Rustam - PhD student at ISMA University of Applied Sciences (ISMA) (Riga, Latvia). Sphere of scientific interest: supply chain management, supply chains of international construction companies, principles of social responsibility in international business, sustainable development goals in the context of supply chains formation of international companies. E-mail: rustam.aslan@gmail.com

IEP, No. 32-33 (2020), pp. 80-98

(C) Deniss Djakons, Rustam Aslanzade, 2020 «All rights reserved»

ISSN 1811-9832/2020/No. 1-2 (32-33) 


\section{Introduction}

There are deep transformational processes happening in the world economy at the beginning of the XXI century under the influence of economic globalization, informatization and virtualization. These global changes are reflected both in the economies of all countries of the world and in the activities of all economic entities, and, of course, in the system of all relations among them.

The formation of global value chains (GVCs), as well as global supply chains (GSCs), is happening under the influence of a whole set of global trends, including: increase in the importance of social responsibility, the role of human capital, active implementation of new technologies, etc. The implementation of social responsibility in the activities of low-tech companies, in particular companies and firms, which operate in this market and create infrastructure facilities, has a high level of relevance. For such companies, social responsibility is indicated not only in the production process, but is primarily important for the end result. With the development of scientific and technological progress there is an increasing need to disseminate the tools of social and environmental responsibility of companies, and its implementation in all aspects of business.

Many scientists have devoted their publications to the research of the principles of social responsibility in the context of sustainable development of supply chains, in particular Mani V., Agrawal R. and others $^{3,}{ }^{4}$, G. Markman, Krause D. ${ }^{5}$, Liu Y., Quan B. ${ }^{6}$, D'Eusanio M., Zamagni, A., Petti L. ${ }^{7}$ and others. The implementation of the principles of corporate social responsibility in the supply chains of international construction companies are studied in the works of scientists such as Sertyesilisik B. ${ }^{8}$, Loosemore M., Heng Lim B.T. ${ }^{9},{ }^{10}$, Bo Xia and

\footnotetext{
${ }^{3}$ Mani, V., Agrawal, R., Sharma, V. (2015). Social sustainability in the supply chain: analysis of enablers. Manag. Res. Rev. 38, 1016e1042.https://doi.org/10.1108/MRR-02-2014-0037.

4 Mani, V., Agrawal, R., Sharma, V. (2016). Impediments to social sustainability adoption in the supply chain: an ISM and MICMAC analysis in Indian manufacturing industries. Global J. Flex. Syst. Manag. $12,135 \mathrm{e} 156$. https://doi.org/10.1007/s40171-015-0106-0.

${ }^{5}$ Markman, G.D. and Krause, D. (2016), Theory Building Surrounding Sustainable Supply Chain Management: Assessing What We Know, Exploring Where to Go. J Supply Chain Manag, 52: 3-10. doi:10.1111/jscm.12105

${ }^{6}$ Liu, Y., Quan, B.-T., Li, J., Forrest, J.Y.-L. A Supply Chain Coordination Mechanism with Cost Sharing of Corporate Social Responsibility. Sustainability 2018, 10, 1227.

D'Eusanio, M., Zamagni, A., Petti, L. (2019). Social sustainability and supply chain management: Methods and tools. Journal of Cleaner Production, Volume 235, pp. 178-189. https://doi.org/10.1016/i.iclepro.2019.06.323

8 Sertvesilisik B. (2016). Embending Sustainability Dynamics in the Lean Construction Supply Chain Management / Begum Sertyesilisik // YBL Journal of Built Environment. Vol.4, Issue 1. - 2016. - URL: https://content.sciendo.com/view/journals/jbe/4/1/article-p60.xml.

${ }_{9}^{9}$ Loosemore, M., Heng Lim B.T. (2017). Linking corporate social responsibility and organizational performance in the construction industry, Construction Management and Economics, 35:3, 90-105, DOI: 10.1080/01446193.2016.1242762

${ }^{10}$ Loosemore, M., Heng Lim B.T. (2018). Mapping corporate social responsibility strategies in the construction and engineering industry, Construction Management and Economics, 36:2, 67-82, DOI: 10.1080/01446193.2017.1326616
} 
others ${ }^{11}$. However, studies of corporate social responsibility practices of international companies in the context of the development of their supply chains are currently insufficiently explained in international scientific publications and need further study.

\section{Leaders and trendsetters in the development of corporate social responsibility policies in construction}

One of the key trends in modern business development, including construction, is the growing importance of environmental friendliness of resources, materials and technologies. Today, the world's largest construction companies determine the current trends in the formation of social responsibility policy. For example, Vinci Construction, the world's largest construction company, has developed an integrated approach to supply chain management, which is characterized by continuous improvement, innovation and sustainable procurement. In the supply chain, special attention is paid to the development of small and medium-sized businesses, especially local ones. The share of local small businesses in the supply chain in 2017 increased from 73 to $78 \%$ (the company has a total of 4.792 suppliers, $85 \%$ of which are accredited under security schemes and $70 \%$ are registered with Construction online) $)^{12}$.

Long-term, stability and consistency principles are the basis of the company's supply chain formation. The company's network costs amounted to $79 \%$ in 2017. For this item of expenditures, strategic supply chain assessment indicators have been developed. One of the key indicators of supply chain management is the measurement of productivity, according to which 3.622 reports were prepared in 2017.

Moreover, the working group on VINCI business in Great Britain has developed a kind of manifesto on slavery (or forced labor, including child labor, which is especially true for countries with low levels of development). A supply chain map was developed to provide a favourable approach to risk assessment, including training, education and chain management in high risk areas. Special modules of e-learning are included to improve the skills of employees and the efficiency of the supply chain in the educational process of VINCI Academy.

Overall, VINCI Facilities have developed reliable, coordinated supply chains aimed at provision of the high-quality collaborative solutions

\footnotetext{
11 Xia, A. Olanipekun, O. et al. (2018). Conceptualising the state of the art of corporate social responsibility (CSR) in the construction industry and its nexus to sustainable development / B. Xia, A. Olanipekun, Q. et al. Chen and others // Journal of Cleaner Production. Volume 195, 2018, pp. 340-353. - 2018. - URL: https://doi.org/10.1016/j.jclepro.2018.05.157.

${ }_{12}$ Vinci Construction. Our Sustainable Business 2019. - Watford, Hertfordshire, UK. - 2019. URL: https://www.vinciconstruction.co.uk/downloads/sustainability-brochure.pdf
} 
needed by customers. At the same time, one of the main conditions for inclusion in the supply chain is the need to share the company's values in terms of social and environmental responsibility, to ensure the quality and professionalism expected from VINCI's employees. The company has also developed a Supplier-Customer Relationship in Action (SCRIA) process to proactively manage its interaction with all suppliers. In practice, the process creates trust between the partners, allowing to discuss problems openly and constructively, without declaration of the culprits. Suppliers participate in the bidding phase, which makes them an integral part of the process of gathering information, developing principles and rules for contracts, as well as giving them the opportunity to understand the real requirements of the market and the company to social responsibility ${ }^{13}$.

The second place in the context of the implementation of social responsibility in the world, in our opinion, is taken by the construction ACS Group Directory. In this company, procurement departments are responsible for management of relationships with suppliers and contractors through special systems of management, classification, approval and risk control. Group's competitive advantage is a clear decentralization of procurement and supplier management departments, which provides the Group's companies with flexibility and autonomy.

ACS has many chain systems that vary depending on the operational needs of companies. Central Corporate Reference Division sets policies and prices with a high degree of autonomy, but always using a single common policy. In 2018, the ACS Group's Board of Directors approved the ACS Code of Conduct for Business Partners, which sets out the principles and rules of action which their business partners must follow in their relations with the ACS.

Even if the supplier is selected by the customer and has not previously been included in the group or supply chain, he must meet the company's standards and be tested for compliance with the Code. The overall supplier verification system includes several basic criteria, both financial and non-financial: cost, payment period, work experience, professional prestige and technical capabilities; history of fulfillment of contractual provisions and previous relations with the ACS Group; additional non-financial criteria related to compliance with the Code of Conduct for Business Partners. Therefore, the company has developed the following criteria for non-financial evaluation of its suppliers (Table 1).

\footnotetext{
13 Vinci Construction. Supply chain. - Watford, Hertfordshire, UK. - 2019. URL:
} 
Table 1

USE OF NON-FINANCIAL CRITERIA WHEN CHOOSING SUPPLIERS ${ }^{14}$ (\%)

\begin{tabular}{|l|c|c|}
\hline \multicolumn{1}{|c|}{ Criteria } & $\mathbf{2 0 1 7}$ & $\mathbf{2 0 1 8}$ \\
\hline Observation of Code of Conduct of the ACS Group & $97.0 \%$ & $96.9 \%$ \\
\hline $\begin{array}{l}\text { Observation and compliance with international human rights } \\
\text { standards and labor market rules }\end{array}$ & $90.3 \%$ & $92.7 \%$ \\
\hline Certification according to quality standards (ISO9001) & $98.2 \%$ & $99.5 \%$ \\
\hline $\begin{array}{l}\text { Certification in aspects of environmental protection (ISO14001, } \\
\text { EMAS or equivalent) }\end{array}$ & $98.3 \%$ & $99.5 \%$ \\
\hline $\begin{array}{l}\text { Analysis of labor standards and practices of suppliers or } \\
\text { subcontractors }\end{array}$ & $96.2 \%$ & 98.45 \\
\hline
\end{tabular}

There are special procedures for supplier approval in the ACS Group: ensuring the feedback and guarantees of compliance with contractual provisions and agreements; identification of economic, environmental and social risks; decision-making or adjustment of management measures. With the aim to do this, a whole system of internal and independent audits, which are conducted on a regular basis, was created. In the event of any nonconformity or risk has been identified, appropriate corrective action shall be taken, taking into account the following circumstances: if the supplier is critically important to the company, the reasons for the negative evaluation are analyzed and initiatives are proposed to strengthen the areas, identified for improvement, including, in particular, training and joint activities; if the company is not critical to the ACS, it is classified as approved in the database; in the event of serious breaches, the contract or agreement with the suppliers may be terminated immediately.

As a result of the analysis, ACS Group identifies critical suppliers in its supply chains. ACS Group evaluated 2.307 suppliers that are considered the best in terms of sustainability in $2018^{15}$ (Table 2).

Among the leaders in the formation of trends in corporate social responsibility policies, the third place belongs to Bechtel, which works only with qualified suppliers and subcontractors who are committed to timely and within the budget, safely and responsibly deliver quality goods and services. Although quality, cost and timeliness are important,

\footnotetext{
${ }^{14}$ ACS Group. Suppliers and contractors. / ACS, Actividades de Construcción y Servicios, S.A. - 2019. URL: https://www.grupoacs.com/corporate-responsibility/the-csr-policy-of-the-acs-group/suppliers-and-contractors/ suppliers-and-contractors/, https://www.grupoacs.com/ficheros_editor/File/05_responsabilidad_corporativa/ Cadena\%20de\%20suministro eng.pdf

${ }^{15}$ ACS Group. Suppliers and contractors. / ACS, Actividades de Construcción y Servicios, S.A. - 2019. URL: https:/www.grupoacs.com/corporate-responsibility/the-csr-policy-of-the-acs-group/suppliers-andcontractors/suppliers-and-contractors/
} 
the company does not place orders with suppliers and subcontractors who do not meet safety, ethics, conduct and human rights standards. Bechtel complies with the highest standards of safety, ethics and human rights and expects the same from suppliers and subcontractors.

Table 2

KEY ASPECTS OF BUILDING RELATIONSHIPS WITH STAKEHOLDERS ${ }^{16}$

\begin{tabular}{|c|c|c|}
\hline Stakeholders & Relevant areas for stakeholders & Mechanisms and departments \\
\hline Employees & $\begin{array}{l}\text { - people } \\
\text { - healthy and safe management } \\
\text { - transparency, ethics and honesty } \\
\text { - return to society }\end{array}$ & $\begin{array}{l}\text { - personnel departments of } \\
\text { companies } \\
\text { - employee satisfaction survey } \\
\text { - performance evaluation } \\
\text { - channel of ethics } \\
\text { - prevention committee }\end{array}$ \\
\hline $\begin{array}{l}\text { Suppliers } \\
\text { subcontractors }\end{array}$ & $\begin{array}{l}\text { - conclusion of contracts with the } \\
\text { ACS group } \\
\text { - possibility of payment } \\
\text { - health and safety management } \\
\text { - transparency, ethics and honesty }\end{array}$ & $\begin{array}{l}\text { - procurement departments of } \\
\text { companies and } \\
\text { - supplier approval } \\
\text { management process } \\
\text { - ethical rules }\end{array}$ \\
\hline Industry associations & - all aspects mentioned above & $\begin{array}{l}\text { - participation in associations, } \\
\text { working groups and discussion } \\
\text { forums }\end{array}$ \\
\hline
\end{tabular}

Suppliers and subcontractors must comply with all conditions of the purchase order and notify Bechtel immediately of any actual or potential violations. In this case, suppliers and subcontractors must be familiar with all applicable laws and regulations and always comply with them when performing work. Suppliers and subcontractors should also ensure that similar lower-level contractors provide an identical service to their subcontracts and purchase orders for any part of the work. Compliance with all anti-corruption laws is in particular attention, such as bribery of public officials and private sector employees, including, inter alia, all provisions of the US Foreign Corrupt Practices Act and the UK Bribery Act 2010, as well as any what amendments to it. In addition, the company expects suppliers to comply with Section 1502 of the Dodd-Frank Wall Street Reform and Consumer Protection Act, which seeks to prohibit the use of conflict minerals (gold, tungsten, tantalum and tin) from the Democratic Republic of the Congo or neighboring countries, effectively excluding them from use in production.

16 ACS Group. Management of the relationship with stakeholders. / ACS, Actividades de Construcción y Servicios, S.A. $\quad$-2019. URL: https://www.grupoacs.com/ficheros_editor/File/05_responsabilidad corporativa/00\%20PDFS/6.5.\%20Gesti\%C3\%B3n\%20de $\% 201 \mathrm{n} \% 20 \mathrm{Relaci} \% \mathrm{C} 3 \% \mathrm{~B} 3 \mathrm{n} \% 20 \operatorname{con} \% 201 \mathrm{los} \% 20 \mathrm{Grupos} \%$ $20 \mathrm{de} \% 20$ Inter $\% \mathrm{C} 3 \%$ A 9 s en.pdf 
Bechtel is committed to all human rights, in accordance with the concept, values and rules of the company, as well as the spirit and intentions of the UN Guiding Principles on Business and Human Rights. With this aim Bechtel does not indulge or tolerate any actions that support human trafficking, slavery, enslavement, forced or compulsory labor. The same requirements apply to all suppliers and subcontractors - compliance with laws that require them to be fair to employees and ensure safe and healthy working conditions.

All suppliers and subcontractors must recognize that the government of USA, other governments, and international organizations publish "lists" that identify entities (such as known or suspected terrorists, money launderers, and drug traffickers) that are limited in the implementation of certain or all types of transactions. Suppliers and subcontractors should check such lists before beginning of transactions with any person or subcontractor, including financial institutions. The purpose of such inspections should be the assurance that all participants in the supply chain are not identified in any safety lists.

There is an "no accidents" policy on construction sites at Bechtel. Suppliers and subcontractors must comply with the safety requirements at each Bechtel workplace. At supplier's facilities, the facilities must be operated in a safe manner to always protect the company's staff, agents and employees. In all locations, suppliers and subcontractors must ensure a safe working environment in accordance with applicable international and national laws, regulations and standards.

Bechtel is also working to diversify its workforce and diversify its supply chains. In USA, suppliers and subcontractors must assist small, disadvantaged, women's, veteran's, disabled people's, and hub businesses in search of opportunities to operate. The company strives to be a leader in the design and construction of facilities that are environmentally friendly, socially responsible and have a sustainable and positive impact on local communities. There is the need to develop methods to mitigate the adverse effects on the environment, the development of a network of local suppliers and subcontractors, as well as the development of the local economy among the company's requirements for suppliers and subcontractors ${ }^{17}$.

In addition, all liabilities for suppliers and subcontractors are imposed not only on them but also on their suppliers and subcontractors (i.e. lower level participants throughout the whole supply chain). These

${ }^{17}$ Bechtel. Bechtel's Expectations for Suppliers' and Subcontractors' Conduct. / Bechtel Corporation. - 2017. URL: https://www.bechtel.com/getattachment/about-us/ethics-compliance/shared-values/supplier-subcontractorexpectations/Supplier-and-Subcontractor-Expectations-2017.pdf 
requirements are mandatory and partly reflect Bechtel's corporate values and social responsibility in all matters ${ }^{18}$.

Bechtel is involved in the fulfillment of the goals of the United Nations and the Paris Climate Agreement in the field of sustainable development, in which the world decided to move to cleaner energy, green infrastructure and universal access to clean water. Bechtel has set long-term goals for sustainable development in order to increase the company's contribution to global sustainability. In its recently published Sustainability Report, Bechtel plans to: increase the resilience of five million people to natural disasters through voluntary initiatives; use alternatives to reduce the environmental impact of $100 \%$ of production facilities, including their suppliers; involve 100 percent of its key suppliers in ensuring sustainability, including through their own supply chains.

These goals are important for business, as sustainability measures can improve a company's financial performance by increasing the number of chain members. In 2015, Bechtel delivered the Watts Bar Unit 2 nuclear reactor to the Tennessee Valley administration. The commissioned Unit 2 is connected to the existing unit to generate nearly 2.300 megawatts of clean, carbon-free electricity, enough to power 1.3 million homes and businesses in the Tennessee Valley. In addition, with the help of Bechtel, Engineers Without Borders (EWB) and local partners, about 600 rural people in remote northwestern Honduras will have access to clean water. EWB and Bechtel are also working with leaders of the Mikomaho community in Uganda to provide safe, clean water for more than 1.700 people. Therefore, building a socially responsible chain is one of Bechtel's key priorities.

\section{Followers}

It is worth noting that not only large and world-famous companies comply with the principles of social responsibility. Therefore, Belimo Company, engaged in the production of industrial climate equipment and machinery for industrial use of water, requires its suppliers to sign a contract-declaration, which formulates liabilities to comply with the basic conditions of social responsibility under the "Belimo Code of Conduct - Behavior in the work environment». This agreement stipulates compliance with the principles and requirements of the Code in addition to the liabilities under Supply Agreement with Belimo. If the supplier has standards different from Belimo, it undertakes to adapt its norms to the Company Code. According to these norms, all suppliers

\footnotetext{
18 Bechtel. Supplier \& Subcontractor Expectations. / Bechtel Corporation. - 2019. URL: https://www.bechtel.com/about-us/ethics-compliance/shared-values/supplier-subcontractor-expectations/
} 
are obliged to submit a written report once a year on the measures taken to ensure social responsibility, and any participant in the supply chain can check this report for compliance with the conditions and requirements of social responsibility. If the supplier or subcontractor violates the rules or obstructs the inspection, Belimo has the right to cancel the existing Supply Agreement. Serious violations of the Code of Conduct include, in particular: child labor, corruption and bribery, significant violations of worker protection, and environmental legislation.

Belimo not only associates sustainability with the need to minimize the negative effects of business processes, but also with the increase in the positive effects. Products manufactured by Belimo facilitate the implementation of solutions that create measurable sustainability benefits. For example, energy savings through heating, ventilation and air conditioning (HVAC) systems in commercial buildings, which account for about $40 \%$ of global energy consumption and climateharmful CO2 emissions ${ }^{19}$.

Intelligent control of heating, ventilation and air conditioning systems greatly affects the energy efficiency of buildings. Thus, the company's responsibility is very high, which leads to the need to build a supply chain that meets the high requirements of the company. In line with the goals of the United Nations, its products and as a member of the Global Compact of this organization, Belimo makes an active contribution to sustainable development, which is also targeted at several stakeholder groups at Belimo and aims to create added value for all these groups.

For its suppliers, the company provides compliance with standards and environmental regulations. Thus, the main companies and suppliers of Belimo, located in Hinesville (Switzerland), Danbury (Connecticut, USA) and Sparks (Nevada, USA), must meet the international standards of environmental management ISO 14001, as well as be regularly audited by the Swiss Association of Quality and Management Systems (SQS). In addition, the use of all suppliers' materials is governed by RoHS and REACH rules, which are designed to determine the use of important materials.

Belimo has a wide range of suppliers that meet the company's social responsibility standards ${ }^{20}$. Most of these companies are located in Europe, but $23 \%$ of suppliers operate in regions with a high risk of

\footnotetext{
19 Belimo. Sustainability Report. / Belimo Holding AG, Hinwil (Switzerland) - 2018. URL: https://www.belimo.com/mam/corporate-communications/investor-relations/financialreports/2018/Sustainability Report 2018.pdf

20 Belimo. Belimo Annual Report 2018. / Belimo Holding AG, Hinwil (Switzerland) - 2018. URL: $\mathrm{https} / /$ www.belimo.com/mam/corporate-communications/investor-relations/financialreports/2018/Sustainability_Report_2018.pdf
} 
social responsibility, which indicates careful selection and control of suppliers. At the same time, conscientious selection of materials used is aimed at minimizing the negative impact on the environment. Auxiliary materials, such as solvents, resins, paints or lead and chromium, are not used at all or are used in very small quantities. Cardboard packaging from suppliers based in the European Union and the United States is made in accordance with the recommendations for the disposal of symbols (RESY). This means that all transport packaging consists of environmentally friendly materials and can be recycled. Due to the consistent use of reusable cardboard packaging between Belimo points and suppliers, packaging material is stored and recycled ${ }^{21}$.

More than 85\% of Belimo's production costs are accounted for by a network of suppliers and partners with the same environmental and social standards. These requirements are identified in the Supplier Code of Conduct and reflect the content of internal management principles. The Code of Conduct was signed by more than 300 suppliers, which is about $90 \%$ of procurement volume. Both new and existing suppliers are regularly checked for compliance with these parameters.

In addition, the transfer of knowledge and technology between production sites ensures safe, efficient and resource-saving production processes. Environmental aspects are given priority in the regular review and adjustment of logistics processes. Standardized reusable packages are increasingly used to deliver materials between Belimo sites, allowing them to be automatically stored or processed without the need for repackaging.

Moreover, waste is recycled or disposed at internal collection points, which allows to recycle more than half of the waste. In Hinesville, the remainder that cannot be recycled is sent to a nearby waste incineration plant, and the utilization of transportation is consolidated (Fig. 1).

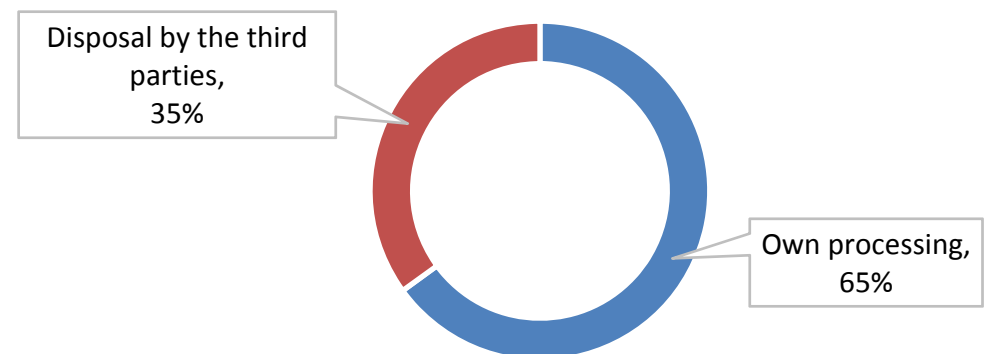

Fig.1. Belimo waste sales structure (including suppliers), \%, 2018

\footnotetext{
21 Belimo. Suppliers. / Belimo Holding AG, Hinwil (Switzerland) - 2018. URL: https://www.belimo.com/en_US/about/belimo/supplier-relationship-management.html

${ }_{22}$ Belimo. Belimo Annual Report 2018. / Belimo Holding AG, Hinwil (Switzerland) - 2018. URL: https://www.belimo.com/mam/corporate-communications/investor-relations/financialreports/2018/Sustainability_Report_2018.pdf
} 
Garbage sent to the waste incineration plant is returned to the company in the form of energy. Thus, the office, production and logistics facilities in Hinesville are heated by a nearby waste incineration plant, which is connected to the district heating network. The comfort and energy efficiency of the premises are constantly monitored and technically upgraded. Analysis of data on the environment and facilities provides a basis for decision-making on optimization projects and aims to improve comfort, energy efficiency and safety.

With the aim to ensure the supply chain, the company is gradually switching to electric vehicles, there are 8 charging points for electric vehicles only in the main building. This has significantly improved the climate in the logistics sector and increased the energy efficiency of the building. Houses in Danbury and Sparks (USA), as well as in Grassobbio (Italy) are certified according to LEED gold standards for sustainable construction. Therefore, the company complies with the principles of transition to the evaluation of buildings in category $\mathrm{A}+$.

Another company operating in the market of industrial and commercial equipment, heating, ventilation and air conditioning Carel (Italy), which is present in more than 80 countries $^{23}$. Like most companies operating in the climate equipment market, it focused its activities and social responsibility on environmental issues. The concept of sustainable development is applied to the entire production chain, in fact, attention to the environment is an important element of business for the company. CAREL's sustainable development policy is aimed at combining environmental needs in accordance with local and international regulations with the Company's system of values and responsibilities.

All CAREL departments and branches must comply with high standards of sustainability and comply with the basic principles of social and environmental issues within their Code of Ethics and the following policies: diversity policy, human rights policy, environmental policy, workplace health and safety policy ${ }^{24}$.

CAREL is globally engaged in the development, production and marketing of technologically advanced components and solutions (hardware and software) to achieve high energy efficiency in the management and regulation of equipment and systems in the markets of air conditioning ("HVAC") and cooling ("HVAC/R" in general).

\footnotetext{
${ }^{23}$ CAREL Group. CAREL in the world. / CAREL Group - Official website. URL: https://www.carel.com/carelin-the-world

24 CAREL Group. CAREL and Sustainability. / CAREL Group - Official website. URL: https://www.carel.com/carel-and-sustainability
} 
The company's activities worldwide requires the construction of a supply chain, which, in 2018, involved 555 suppliers and chain participants, manufacturers is dominated by value of turnover (more than $71 \%)^{25}$.

CAREL prefers to use local suppliers. In particular, in the total cost of procurement in 2018, approximately $69 \%$ of suppliers are located in Europe, about 29\% - in Asia and the remaining 2\% - in America, Middle East and Africa. This division is due to the fact that European and Chinese suppliers serve plants both in the EU and abroad. A special role is played by the CAREL plant in Suzhou, which centralizes the procurement of materials from Chinese and Asian suppliers to distribute them to all production sites of the Group.

The choice of suppliers is based on the principles of impartiality, competence, competition and economy, in addition to the principles of transparency and excellence in accordance with the highest quality standards. Supply relations are based on compliance with the country's laws and regulations on labor, human rights, health and safety, environmental protection and anti-corruption legislation, as well as the application of the principles set out in the CAREL Code of Ethics $^{26}$. Each provider is also obliged to guarantee respect for fundamental human rights, the principles of equal treatment and nondiscrimination, as well as the protection of children and the avoidance of forced labor.

The selection of suppliers is carried out by CAREL also taking into account technical skills, quality of goods/services, timeliness of delivery, prices and terms of payment and, more generally, terms of purchase. The company demands high productivity from its suppliers in terms of cost, quality, service and sustainability. All suppliers are preapproved according to the procedures certified by the ISO 9001 quality management system.

CAREL believes that it is extremely important to intensify and maintain a constant dialogue and transfer of best practices and competencies to its suppliers, as it is extremely important to receive quality products and services. This dialogue takes place using various tools: visits of technicians and subjects responsible for quality control: IT platforms (e.g. IUNGO) adopted as information channels for customers/suppliers, including management and updating of existing orders through suppliers.

CAREL's supply chain consists of national and international suppliers, so it must be constantly monitored and updated considering

25 CAREL Group. Supply Chain Management. / CAREL Group - Official website. URL: https://www.carel.com/supply-chain-management 
the significant risks and the fact that the supply chain contains the components necessary for production. With the aim to ensure the availability of the material for the production stages, to diversify the risk and to have adequate guarantees of compliance with the expected time of market entry, CAREL plans its production on time and ensures an increase in the share of components supplied by at least two suppliers.

Additional risks are associated with the protection of the environment, human rights and the health and safety of workers. In particular, CAREL runs the risk that its suppliers do not comply with the Group's quality standards and are subject to regulations relating to labor and social security, health and safety at work, the supply of raw materials, defective components or compliance with certain quantitative indicators. The tools currently used by CAREL to manage these risks are supplier selection and previous screening of their structures through study visits to verify compliance with corporate standards. The inspection includes, inter alia, technical screening of equipment and facilities and inspection of the working environment ${ }^{27}$.

One of the main conditions of the company is strict compliance with applicable laws and regulations to protect the environment, reduce pollution and promote high performance in the construction sector. In addition, CAREL in the development of its industrial activities promotes scientific and technical specialization related to environmental protection and conservation of resources. In this regard, the company's activities related to the management of environmental aspects are controlled by specialized resources in CAREL INDUSTRIES SpA and in CAREL Electronic (Suzhou) Co. Ltd., as both facilities are certified according to the international standard ISO 14001: 2015 and for their purposes, they present some specific environmental policies that are in line with the policy defined at the group level.

CAREL's current management approach involves assessment of their energy efficiency when selecting production equipment, vehicles designed to transport people and things, as well as technical and technological systems. For example, although there are no structured programs to improve energy efficiency, CAREL INDUSTRIES SpA is implementing some initiatives to replace lighting fixtures with lowpower LEDs, replace cars with internal combustion engines with hybrid cars, improve thermal insulation for buildings (external coverings and blinds for window surfaces). In addition, over the next few years it is planned to double the capacity of the plant in China (CSZ, CAREL Electronic - Suzhou) and expansion of the plant in USA (CUS,

\footnotetext{
${ }^{27}$ Ibid.
} 
CAREL USt), which is expected to increase by 9\% compared to 2019. This will determine the trend of increase of consumption and related emissions of the company's enterprises, despite the fact that the new sections of production sites were designed with maximum efficiency of installations. It is also planned to improve efficiency at CAREL Adriatic $(\mathrm{CHR})$, in particular with the help of introduction of a new air conditioning unit.

Remaining a priority goal for CAREL, environmental protection and protection of natural resources receive varying degrees of attention on production sites and in foreign commercial branches according to the geographical region where they are located, both for regulatory reasons and due to the availability of resources. Thus, factory and legal differences impose certain restrictions and necessary clarifications on emissions into the atmosphere. For example, ozone-depleting substances vary depending on the systems and refrigerants used. Periodic maintenance is performed for all installations according to the annual planning to ensure the highest level of efficiency and to reduce the consumption of ozone-depleting gases. With regard to $\mathrm{NOx}, \mathrm{SOx}$ and other significant emissions into the atmosphere, the plant in Brazil (CSA, CAREL South America) is not subject to "Volatile Organic Compounds" (VOC).

In Italy, at CAREL Industries SpA, the analysis of pollutant emissions into the atmosphere shows levels below the limits set by the existing permits. Regular scheduled maintenance of burners is carried out for CAREL Adriatic (CHR), as well as periodic analysis of emissions in connection with the legal obligation to protect the environment. A separate program works for CAREL Suzhou (CSZ), where sample tests for quality control of production and supply are developed by an external office ${ }^{28}$.

\section{Forms of social responsibility of international construction companies in supply chains}

The results of the study show that the most common forms of socially responsible activities of companies are: ecological certification of the company's products or services, certification of the production process according to international standards (introduction of the quality management system according to ISO 9001, environmental management system according to ISO 14001, etc.), ensuring decent pay and working conditions for the population of the region of the company's presence (Table 3).

\footnotetext{
28 CAREL Group. Environmental Protection. / CAREL Group - Official website. URL: https://www.carel.com/environmental-protection
} 
Table 3

\section{FORMS OF SOCIALLY RESPONSIBLE ACTIVITY OF INTERNATIONAL CONSTRUCTION COMPANIES IN SUPPLY CHAINS}

\begin{tabular}{|c|c|c|c|c|c|c|c|}
\hline $\begin{array}{c}\text { Forms of indicators of socially responsible position on } \\
\text { the construction of the supply chain }\end{array}$ & 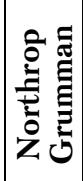 & 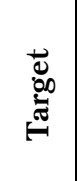 & $\begin{array}{l}\bar{U} \\
\mathbf{Z} \\
\vec{\gamma}\end{array}$ & 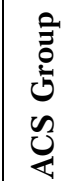 & 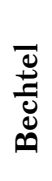 & 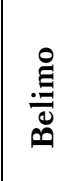 & 究 \\
\hline $\begin{array}{l}\text { Existence of the Code of Conduct and Social } \\
\text { Responsibility of the company }\end{array}$ & + & + & + & + & + & + & + \\
\hline Ecological certification of finished products & + & + & + & + & + & + & + \\
\hline Production of eco-products & - & - & - & - & + & - & - \\
\hline $\begin{array}{l}\text { Ensuring a sufficient level of remuneration and work } \\
\text { conditions for both the company and suppliers }\end{array}$ & + & + & + & + & + & + & + \\
\hline $\begin{array}{l}\text { Observation and compliance with international human } \\
\text { rights standards and labor market rules }\end{array}$ & + & - & + & + & + & + & + \\
\hline Suppliers' compliance with environmental standards & $+/-$ & + & + & + & + & + & + \\
\hline $\begin{array}{l}\text { Certification in aspects of environmental protection } \\
\text { (ISO14001, EMAS or equivalent) }\end{array}$ & + & + & + & + & + & + & + \\
\hline $\begin{array}{l}\text { Quality regulation of supplied materials and their } \\
\text { compliance with RoHS and REACH (or equivalent) }\end{array}$ & + & + & + & + & + & $+/-$ & $+/-$ \\
\hline $\begin{array}{l}\text { Analysis of labor standards and practices of suppliers or } \\
\text { subcontractors }\end{array}$ & $+/-$ & $+/-$ & + & + & + & $+/-$ & $+/-$ \\
\hline Regulating the disposal of RESY products (or equivalent) & $+/-$ & $+/-$ & $+/-$ & $+/-$ & + & $+/-$ & $+/-$ \\
\hline
\end{tabular}

Note: “+" - the form of indicators is presented in full, “+/-" - is partially represented, “-" - is not represented.

Assessment of the company's social responsibility from the point of view of supply chain formation has its own peculiarities. This approach allows us to assess the sequence of implementation of social responsibility (in all its forms) at all stages of the production cycle. The study and analysis of the existing experience of advanced companies allows to systematize the existing practices of international companies in terms of forming efficient supply chains (Table 4). 
CHARACTERISTICS OF THE STAGES OF BUILDING A SUPPLY CHAIN ON THE BASIS OF SOCIAL RESPONSIBILITY ${ }^{29}$

\begin{tabular}{|c|c|c|c|c|}
\hline Stages & $\begin{array}{l}\text { Building your own } \\
\text { corporate model } \\
\text { social } \\
\text { responsibility }\end{array}$ & $\begin{array}{l}\text { Search and } \\
\text { selection of } \\
\text { suppliers and } \\
\text { contractors }\end{array}$ & $\begin{array}{l}\text { Building a model of } \\
\text { control over suppliers } \\
\text { and contractors }\end{array}$ & $\begin{array}{l}\text { Building a supply } \\
\text { chain based on the } \\
\text { principles of social } \\
\text { responsibility }\end{array}$ \\
\hline \multirow[t]{2}{*}{$\frac{\pi}{\widetilde{J}}$} & $\begin{array}{l}\text { Development of } \\
\text { own Code of } \\
\text { Conduct and } \\
\text { Social } \\
\text { Responsibility }\end{array}$ & $\begin{array}{l}\text { Existence of a clear } \\
\text { system of selection } \\
\text { of suppliers and } \\
\text { contractors: criteria } \\
\text { and requirements to } \\
\text { them; } \\
\text { cooperation with } \\
\text { suppliers; } \\
\text { involvement of } \\
\text { local suppliers }\end{array}$ & $\begin{array}{l}\text { Management of } \\
\text { relations with } \\
\text { suppliers and } \\
\text { contractors on the } \\
\text { basis of constant } \\
\text { control over their } \\
\text { observance of all basic } \\
\text { principles of social } \\
\text { responsibility of the } \\
\text { company }\end{array}$ & $\begin{array}{l}\text { Existence of a } \\
\text { single end-to-end } \\
\text { supply chain system } \\
\text { based on the } \\
\text { principles of social } \\
\text { responsibility, } \\
\text { efficiency and } \\
\text { sustainability }\end{array}$ \\
\hline & \multicolumn{4}{|c|}{$\begin{array}{l}\text { Socially responsible personnel management; } \\
\text { Participation in charitable projects; } \\
\text { crimination in the labor process, use of forced and child labor; } \\
\text { servance of all laws, especially in the field of anti-corruption. }\end{array}$} \\
\hline 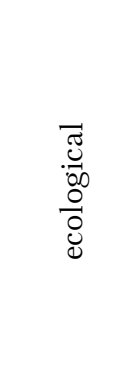 & \multicolumn{4}{|c|}{$\begin{array}{l}\text { - Production of products and services taking into account environmental requirements } \\
\text { and ISO quality standards; } \\
\text { - Maximizing the service life or use of products; } \\
\text { - Encouraging reuse / recycling, product disposal; } \\
\text { - Minimization of total costs / carbon footprint; use of renewable energy sources, } \\
\text { secondary raw materials; green sources of direct and indirect materials, alternative } \\
\text { fuels and improved fuel efficiency; } \\
\text { - Reduction of pollutant emissions during production; additional filters in production, } \\
\text { water reuse; } \\
\text { - Provision of reliable information about the product, its features and impact on } \\
\text { human health, the environment. }\end{array}$} \\
\hline$\cdot \frac{n}{\underbrace{n}_{0}}$ & \multicolumn{4}{|c|}{$\begin{array}{l}\text { - Construction of an optimal and economical logistics chain, taking into account the } \\
\text { availability of the most economical and harmless materials, the maximum reduction of } \\
\text { time, costs and distance for product delivery; } \\
\text { - Construction of efficient transport systems; optimization of sea, air and rail } \\
\text { transportation; } \\
\text { - Reduction of transport emissions; design and use of reverse logistics systems; } \\
\text { - Strategically located warehouses and distribution centers; } \\
\text { - Improved warehouse planning; } \\
\text { - Consolidation of incoming and outgoing traffic using cargo transportation; } \\
\text { - Reduction of volumes and total weight of shipped goods; } \\
\text { - Reduction of nodes during transportation; } \\
\text { - Optimization of road transport and reduction of free places in trailers; } \\
\text { - Reduce mileage and improve vehicle fleet usage }\end{array}$} \\
\hline
\end{tabular}

${ }^{29}$ Developed by the authors. 
Therefore, according to the table, social responsibility in the created supply chains has at least three aspects - social, environmental and logistical. At the same time, the creation of a supply chain on the basis of social responsibility goes through several stages, which are characterized by certain corporate efforts, which we attribute to the group of social. At the same time, environmental and logistical indicators of socially responsible activities can be observed at all stages of building supply chains.

\section{Conclusions}

The formation of a system of various supply chains on the principles of social responsibility involves monitoring compliance with ethical principles throughout the supply chain. All suppliers go through an evaluation process that identifies companies that are at risk of declining productivity. Effectiveness is assessed by several main categories, including: management, technical support, schedule, cost, supply, mission implementation, supply chain management and customer satisfaction with an emphasis on the "most important suppliers" basic business requirements. Supply chain control focuses on preventing product from defects at all stages of production, banning counterfeit parts and cybersecurity, protection of intellectual property, for which there was developed a special educational program of the reliability of materials for supply throughout the chain, improvement of product quality, engineering, etc. Moreover, only those suppliers who have been trained or tested to prevent the production from defects or entry into the chain with defective products are admitted to the supply chain. At the same time, one of the key components of building a company's supply chain is assurance of occupational safety for employees. Particular relevance is the introduction of social responsibility in the activities of construction companies and companies involved in the creation of infrastructure. The world's largest construction companies must comply with social responsibility policies, including the management of supply chains.

In modern conditions, it is important not just the commitment of companies to the principles of social responsibility. A higher level of social responsibility of the company is a situation where the company thinks not only about its internal activities, but also builds the entire supply chain on the principles of social responsibility. Therefore, by setting requirements for all its potential contractors, the company has repeatedly expanded its socially responsible impact on the business environment globally. 


\section{References}

1. ACS Group. Suppliers and Contractors. / ACS, Actividades de

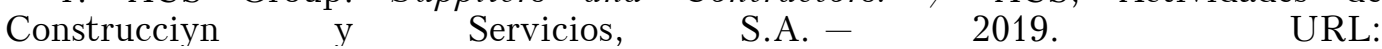
https: / / www.grupoacs.com / corporate-responsibility / the-csr-policy-of-the-acsgroup/suppliers-and-contractors / suppliers-and-contractors /, https: / / www.grupoacs.com / ficheros_editor /File /05_responsabilidad_corporati va/Cadena\%20de\%20suministro eng.pdf

2. ACS Group. Management of the relationship with stakeholders. / ACS, Actividades de Construcciyn y Servicios, S.A. - 2019. URL: https: / / www.grupoacs.com/ficheros_editor /File /05_responsabilidad_cor porativa /00\%20PDFS $/ 6.5 . \% 20 \mathrm{Gesti} \% \mathrm{C} 3 \% \mathrm{~B} 3 \mathrm{n} \% 20 \mathrm{de} \% 201 \mathrm{l} \% \overline{20}$ Relaci $\% \mathrm{C} 3 \% \mathrm{~B} 3 \mathrm{n} \% 2$ 0con\%20los\%20Grupos\%20de\%20Inter\%C3\%A9s_en.pdf

3. Bechtel. Bechtel's Expectations for Suppliers' and Subcontractors' Conduct. / Bechtel Corporation. - 2017. URL: https://www.bechtel.com/ getattachment/about-us / ethics-compliance/shared-values / suppliersubcontractor-expectations / Supplier-and-Subcontractor-Expectations-2017.pdf

4. Bechtel. Supplier \& Subcontractor Expectations, / Bechtel Corporation. - 2019. URL: https://www.bechtel.com/about-us/ethicscompliance / shared-values / supplier-subcontractor-expectations /

5. Belimo. Sustainability Report. / Belimo Holding AG, Hinwil (Switzerland) - 2018. URL: https://www.belimo.com/mam/corporatecommunications / investor-relations / financial-

reports/2018/Sustainability_Report_2018.pdf

6. Belimo. Belimo Annual Report 2018. / Belimo Holding AG, Hinwil (Switzerland) - 2018. URL: https://www.belimo.com/mam/corporatecommunications /investor-relations / financial-

reports/2018/Sustainability_Report_2018.pdf

7. Belimo. Suppliers. T Belimo Holding AG, Hinwil (Switzerland) - 2018. URL: https://www.belimo.com/en_US/about/belimo/supplier-relationshipmanagement.html

8. CAREL Group. CAREL in the world. / CAREL Group - Official website. URL: https://www.carel.com/carel-in-the-world

9. CAREL Group. CAREL and Sustainability. / CAREL Group - Official website. URL: https:/ / www.carel.com/carel-and-sustainability

10. CAREL Group. Supply Chain Management. / CAREL Group - Official website. URL: https: / / www.carel.com/supply-chain-management

11. CAREL Group. Environmental Protection. / CAREL Group - Official website. URL: https:// www.carel.com/environmental-protection

12. D'Eusanio, M., Zamagni, A., Petti, L. (2019). Social sustainability and supply chain management: Methods and tools. Journal of Cleaner Production, Volume 235, pp. 178-189. https://doi.org/10.1016/j.jclepro.2019.06.323

13. Mani, V., Agrawal, R., Sharma, V. (2015). Social sustainability in the supply chain: analysis of enablers. Manag. Res. Rev. 38, 1016e1042.https: / / doi.org/10.1108/MRR-02-2014-0037.

14. Mani, V., Agrawal, R., Sharma, V. (2016). Impediments to social sustainabilityadoption in the supply chain: an ISM and MICMAC analysis in 
Indianmanufacturing industries. Global J. Flex. Syst. Manag. 12, 135e156.https: / / doi.org / 10.1007/s40171-015-0106-0.

15. Markman, G.D. and Krause, D. (2016), Theory Building Surrounding Sustainable Supply Chain Management: Assessing What We Know, Exploring Where to Go. J Supply Chain Manag, 52: 3-10. doi:10.1111/jscm.12105

16. Liu, Y., Quan, B.-T., Li, J., Forrest, J.Y.-L. (2018). A Supply Chain Coordination Mechanism with Cost Sharing of Corporate Social Responsibility. Sustainability 2018, 10, 1227.

17. Loosemore, M., Heng Lim B.T. (2017). Linking corporate social responsibility and organizational performance in the construction industry, Construction Management and Economics, 35:3, 90-105, DOI: $10.1080 / 01446193.2016 .1242762$

18. Loosemore, M., Heng Lim B.T. (2018). Mapping corporate social responsibility strategies in the construction and engineering industry, Construction Management and Economics, 36:2, 67-82, DOI: 10.1080/01446193.2017.1326616

19. Sertyesilisik B. (2016). Embending Sustainability Dynamics in the Lean Construction Supply Chain Management / Begum Sertyesilisik / / YBL Journal of Built Environment. Vol.4, Issue 1. - 2016. - URL: https: / / content.sciendo.com/view / journals /jbe / $4 / 1 /$ article-p60.xml.

20. Vinci Construction. Our Sustainable Business 2019. - Watford, Hertfordshire, $\quad$ UK. - $2019 . \quad$ URL: https: / / www.vinciconstruction.co.uk / downloads / sustainability-brochure.pdf

21. Vinci Construction. Supply Chain. - Watford, Hertfordshire, UK. 2019. URL: https://www.vincifacilities.com/opportunities/supply-chain /

22. Xia, A. Olanipekun, Q. et al. (2018). Conceptualising the state of the art of corporate social responsibility (CSR) in the construction industry and its nexus to sustainable development / B. Xia, A. Olanipekun, Q. et al. Chen and others / Journal of Cleaner Production. Volume 195, 2018, pp. 340-353. - URL: https: / / doi.org/10.1016/j.jclepro.2018.05.157.

The article was received by the Editorial Board on February 10, 2020. 